\title{
Distribution and abundance by larval developmental stages of Symphurus williamsi (Pleuronectiformes: Cynoglossidae) in the Gulf of California
}

\author{
GERARDO ACEVES-MEDINA ${ }^{1}$, RICARDO J. SALDIERNA-MARTÍNEZ1 \\ and ENRIQUE A. GONZÁLEZ-NAVARRO² \\ ${ }^{1}$ Centro Interdisciplinario de Ciencias Marinas-IPN. Departamento de Plancton y Ecología Marina. Apdo. Postal 592, \\ La Paz, Baja California Sur, México. C.P. 23000, E-mail aceves651@ prodigy.net.mx \\ ${ }^{2}$ Universidad Autónoma de Baja California Sur. Departamento de Biología Marina, A.P. 19-B, La Paz, \\ Baja California Sur 23080, México.
}

\begin{abstract}
SUMMARY: Distribution and abundance of tonguefish larvae (Symphurus williamsi) were analyzed from collections made during ten oceanographic surveys in the Gulf of California between 1984 and 1988. Larvae were found mainly during the summer months and the highest abundances were located in the warmer southern and central regions of the Gulf, but they were scarce in the northern portion. High abundance of preflexion larvae occurred in areas where the sea surface temperature was between 29 and $32^{\circ} \mathrm{C}$. Distribution patterns according to developmental stage suggest spatial ontogenic segregation with the early larvae in the ocean area of the central and southern regions of the Gulf. Based on abundance of preflexion larvae as well as on signs of a short egg period of this species, spawns may occur between early and mid summer.
\end{abstract}

Keywords: Symphurus williamsi, Gulf of California, fish larvae.

RESUMEN: Distribución Y ABUNDANCIA POR ESTADIOS DE DESARROLLO LARVAL DE SYMPHURUS WILLIAMSI (CYNOGLOSSIDAE: PleuroneCtiformes) EN El Golfo De CALIFORNIA. - La distribución y abundancia de las larvas del pez lengua (Symphurus williamsi) fue analizada a partir de muestras recolectadas en diez cruceros oceanográficos en el Golfo de California entre 1984 y 1988. Las larvas se encuentran principalmente durante los meses de verano con sus mayores abundancias en las regiones más cálidas del sur y centro del Golfo, pero son muy escasas en la porción norte. La mayor abundancia de larvas en preflexion ocurre en áreas donde la temperatura superficial del mar oscila entre 29 y $32^{\circ} \mathrm{C}$. Asimismo, los patrones de distribución por estadios de desarrollo larval sugieren una segregación ontogénica espacial con las larvas más pequeñas en la zona oceánica de las regiones centro y sur del Golfo. Basados en la abundancia de larvas preflexionadas y en indicios de un estadio de huevo corto de esta especie, suponemos que los desoves deben ocurrir entre principios y mediados del verano.

Palabras clave: Symphurus williamsi, Golfo de California, larvas de peces.

\section{INTRODUCTION}

The tonguefish genus Symphurus contains 71 species in temperate and tropical seas, with 17 species found in the Eastern Pacific and 13 in the Gulf of California (Munroe, 1992). Despite the high abundance of these species in demersal fishery catches in tropical seas (Van der Heiden, 1985) their biology is scarcely understood, as the taxonomy of the eastern Pacific species remained unclear until Munroe (1992) and Munroe et al. (1995) provided sufficient information for identifying adults.

As in all Cynoglossids, Symphurus species have planktonic eggs and initially symmetrically-shaped larvae, which later metamorphose into asymmetrically-shaped juveniles. Behavioural changes of 
asymmetric juveniles coincide with migration from the planktonic to benthonic environments (Charter and Moser, 1996). Knowledge about the ecology of Symphurus larvae in the Eastern Pacific is scarce since only six out of 17 species of this genus (Symphurus atricaudus, S. elongatus, S. williamsi, S. callopterus, S. chabanaudi and S. prolatinaris) have been described in their early life history stages (Evseenko, 1990; Charter and Moser, 1996; AcevesMedina et al., 1999; Evseenko and Shtaut, 2000). General knowledge on the distribution and abundance of Symphurus spp. larvae shows that they are found in the Gulf of California and Eastern Tropical Pacific throughout the year with the greatest abundance during the summer (Ahlstrom, 1972; AcevesMedina et al., 1999); they are found from shallow to deep waters, as with Symphurus civitatus in the Gulf of México (Flores-Coto et al., 1992) and S. callopterus in the central waters of the Eastern Pacific (Evseenko, 1990). There is little available information about $S$. williamsi (Castro-Aguirre et al., 1999); adults have been recorded in shallow waters with sandy bottoms from the Gulf of California to Panama (Munroe et al., 1995). Larvae of this species are one of the most common in ichthyoplankton collections of the Gulf of California (Aceves-Medina et al., 2003a), but no analyses on larval distribution and abundance of this species have been published. This study was performed to contribute to knowledge of the spatial and temporal variations of the larval distribution and abundance of $S$. williamsi in the Gulf of California.

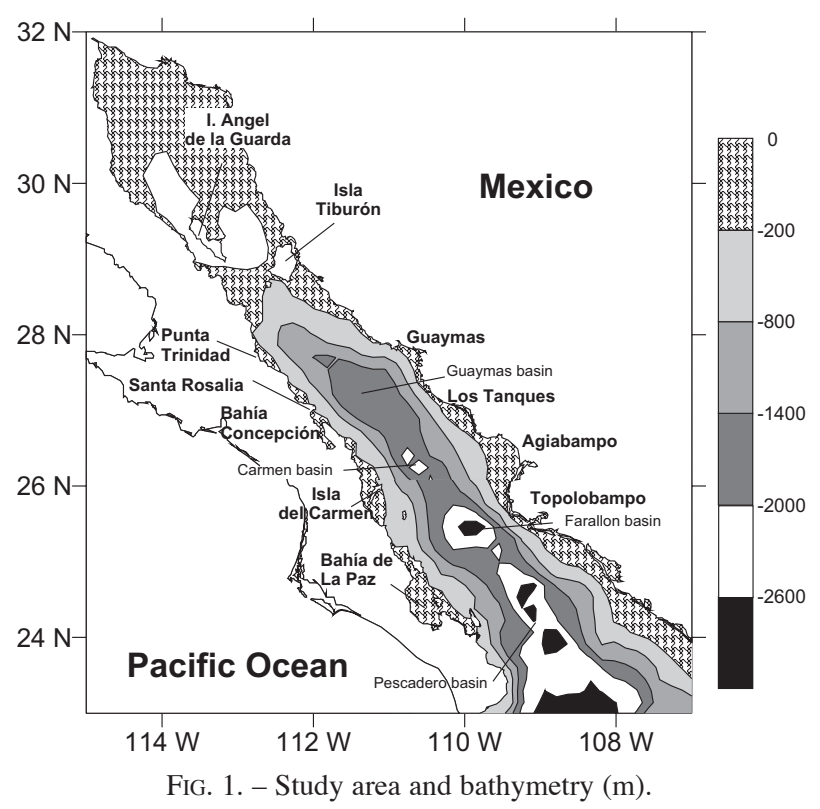

The Gulf of California is a region of high environmental contrasts that affect the distribution of fish fauna. The northern region is shallow ( $200 \mathrm{~m}$ on average), but south of Isla Tiburón and Ángel de la Guarda there are a series of deep basins (Fig. 1). In the northern region, the sea surface temperature (SST) ranges on a seasonal basis from $9^{\circ} \mathrm{C}$ in winter to $38^{\circ} \mathrm{C}$ in summer, while in the southern region, SST ranges from $22^{\circ} \mathrm{C}$ to $31^{\circ} \mathrm{C}$ respectively (SotoMardones et al., 1999). The hydrographic regime includes local upwellings on the east coast during winter and on the west coast during summer. The Gulf water, warm with high salinity, flows towards the south along the Baja California Peninsula's east coast, and the tropical Pacific warm water with lower salinity flows northward along the west coast of the mainland (Alvarez-Borrego, 1983).

\section{MATERIAL AND METHODS}

Ichthyoplankton was extracted from zooplankton samples obtained in ten oceanographic surveys in the Gulf of California during April, July and November-December 1984, April 1985, June, August and November 1986, September and November 1987, and February 1988 (Fig. 2).

Zooplankton samples were collected with oblique Bongo tows at a maximum depth of $210 \mathrm{~m}$, with $333-\mu \mathrm{m}$ and $505-\mu \mathrm{m}$ mesh nets equipped with flow meters to estimate the volume of filtered water. Smith and Richardson (1979) described the sampling method in detail. All fish larvae collected with the 505- $\mu \mathrm{m}$ mesh net were picked from the samples, and Symphurus williamsi larvae were identified according to Aceves-Medina et al. (1999), categorized by developmental stage (preflexion, flexion and postflexion), and counted. Abundance was standardized to number of larvae per $10 \mathrm{~m}^{2}$ of sea surface (Smith and Richardson, 1979).

It was not possible to use egg abundance to identify time of reproduction and spawning areas of $S$. williamsi in the Gulf of California because eggs of the Symphurus species are not described and information about the duration of the egg stage is still unknown in all Cynoglossidae species. Instead, the occurrence of larvae in the preflexion stage, the earliest identifiable stage of this species and that closest to the egg stage, was used as an estimate of a spawn event close to the collection date of these samples. 


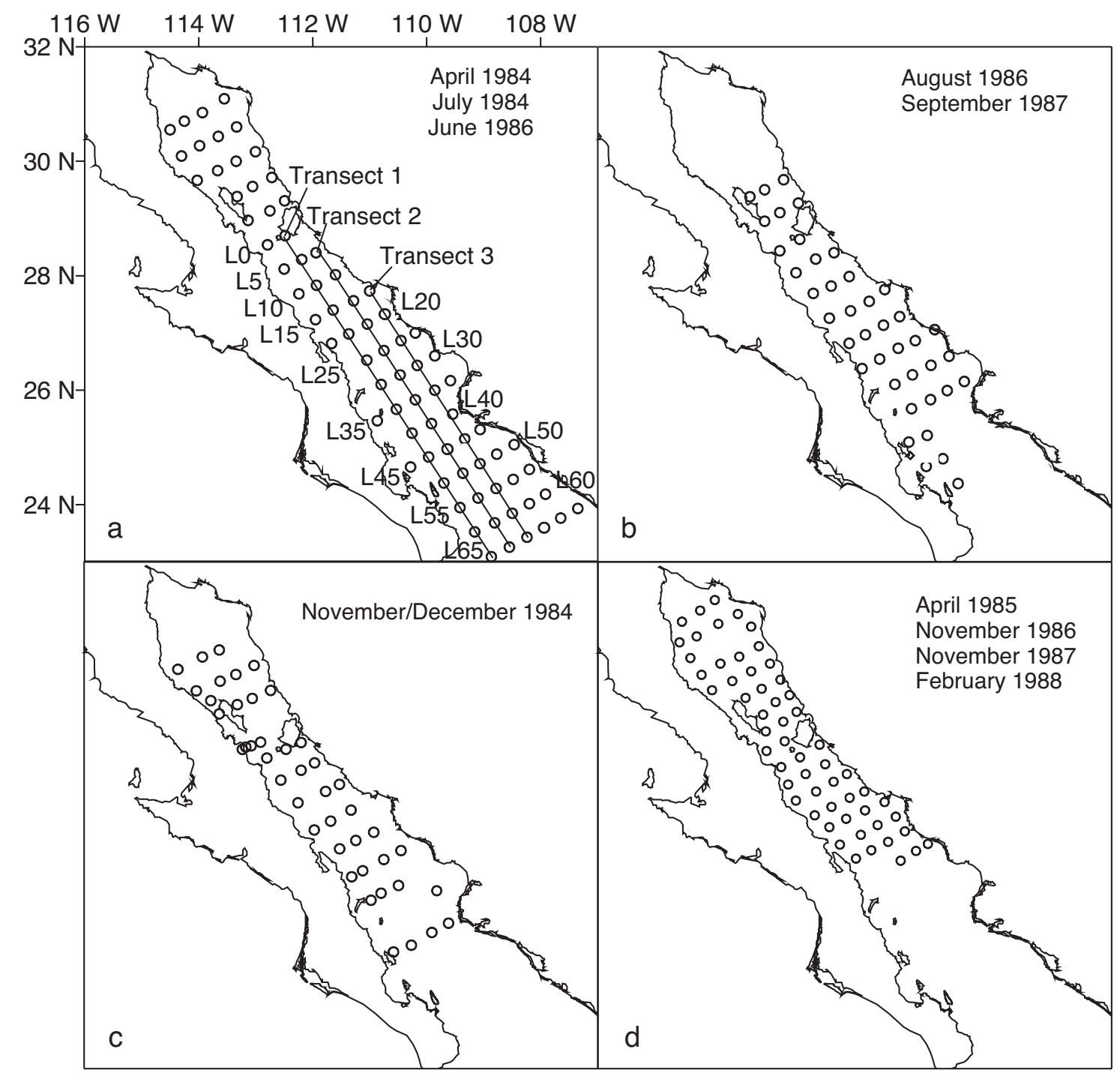

FIG. 2. - Sampling station pattern for surveys in the Gulf of California.

Sea surface temperature (SST) was measured throughout all the surveys with a bucket frame thermometer before each bongo tow. Temperature measurements at $5 \mathrm{~m}$ intervals from surface to $50 \mathrm{~m}$ depth are available only for surveys done in July 1984, August 1986 and September 1987; all temperature records were obtained with reversible thermometers. Vertical profiles of temperature from the surface to $50 \mathrm{~m}$ were performed in three transects of these summer surveys along the east and west coasts and in the middle of the Gulf (Fig. 2); they were compared with larval distribution and abundance along the same transects.

To estimate the probability of finding $S$. williamsi larvae by SST range, we used the SST records from 1984 (207 records), 1985 (53 records), 1986 (131 records), 1987 (91 records) and 1988 (51 records), as well as the larval abundance data set in the equation:

$$
\mathrm{P} i=(\mathrm{n} i / \mathrm{N} i) 100
$$

where $\mathrm{P} i$ is the proportion of stations with preflexion larvae found at $i$ temperature, $n i$ is the number of stations during all the study period with preflexion larvae at $i$ temperature, and $\mathrm{N} i$ is the total number of stations between 1984 to 1988 at $i$ temperature. This index was used together with the percentage of the abundance of preflexion larvae, according to a range of one degree of temperature, to estimate the SST range in which $S$. williamsi larvae are distributed. The same procedure was performed with the 168 temperature records from $50 \mathrm{~m}$, which is the greatest depth at which adults are found (Munroe et al., 1995). 
TABLE 1. - General statistics of larval catches of Symphurus williamsi in the Gulf of California. PF = preflexion stage, FL = flexion stage, and $\mathrm{PO}=$ postflexion stage. Abundance units are in organisms per $10 \mathrm{~m}^{2}$.

\begin{tabular}{|c|c|c|c|c|c|c|}
\hline \multirow[t]{2}{*}{ Survey } & \multirow{2}{*}{$\begin{array}{l}\text { Abundance } \\
\text { per survey }\end{array}$} & \multirow{2}{*}{$\begin{array}{l}\text { Mean abundance } \\
\text { per sample }\end{array}$} & \multirow{2}{*}{$\begin{array}{l}\text { Highest abundance } \\
\text { per sample }\end{array}$} & \multicolumn{3}{|c|}{ Larval occurrence by survey (\%) } \\
\hline & & & & $\mathrm{PF}$ & FL & PO \\
\hline April 1984 & 0 & 0 & 0 & 0 & 0 & 0 \\
\hline July 1984 & 1383 & 34 & 195 & 75 & 16 & 9 \\
\hline Nov/Dec 1984 & 8 & 4 & 4 & 0 & 100 & 0 \\
\hline April 1985 & 0 & 0 & 0 & 0 & 0 & 0 \\
\hline June 1986 & 241 & 17 & 100 & 53 & 22 & 25 \\
\hline Aug. 1986 & 322 & 16 & 45 & 37 & 26 & 37 \\
\hline Nov. 1986 & 0 & 0 & 0 & 0 & 0 & 0 \\
\hline Sept. 1987 & 1175 & 37 & 185 & 68 & 12 & 20 \\
\hline Nov. 1987 & 0 & 0 & 0 & 0 & 0 & 0 \\
\hline Feb. 1988 & 0 & 0 & 0 & 0 & 0 & 0 \\
\hline TOTAL & 3129 & & & & & \\
\hline
\end{tabular}

\section{RESULTS}

The total abundance of Symphurus williamsi larvae between 1984 and 1988 was 3,129 specimens but they were mainly confined to the summer surveys (Table 1). While during April 1984 no $S$. williamsi larvae were found, July had a mean abundance of 34 organisms per sample, with a high catch of 159 organisms per sample and a high proportion of organisms in the preflexion stage $(75 \%)$. Mean abundance decreased during November and December 1984 to 4 specimens per sample with a total of 8 organisms (all of them in the flexion stage). No larvae were found in April 1985.

During 1986 S. williamsi larvae were collected only during the June and August surveys and they did not appear in November (Table 1). Mean abundance per sample was similar in both summer surveys (17 and 16 larvae per $10 \mathrm{~m}^{2}$ respectively), but during June $53 \%$ of the organisms correspond to preflexion larvae compared with $37 \%$ in August. During the next summer (September 1987) a high larval abundance was found again; the mean abundance was 37 organisms per $10 \mathrm{~m}^{2}$ per sample, the highest catch per sample was 185 organisms per 10 $\mathrm{m}^{2}$ and $68 \%$ of the fish larvae were in the preflexion stage. Larvae were absent during November 1987 and February 1988.

The highest abundance of larvae occurred south of $28^{\circ} \mathrm{N}$, but larvae were found throughout the study area in patches of high density alternating with areas of low density or absence of larvae (Fig. 3). Larval distribution according to developmental stages shows high concentrations of preflexion larvae along the central axis of the Gulf. During July 1984, preflexion larvae had a continuous distribution between Isla Tiburón and Bahía de La Paz, with the highest density in the deep regions between Santa Rosalía and Guaymas, in front of Isla del Carmen and in the mouth of the Gulf (Fig. 3a). Distribution of flexion stage larvae during this survey shows three areas of high concentration: between Isla Tiburón and Bahía Concepción; between Bahía Concepción and Bahía La Paz; and south of Agiabampo (Fig. 3b). Postflexion larvae were distributed mainly on the west side of the Gulf but they were more abundant near the Bahía Concepción coast and in the mouth of the Gulf (Fig. 3c). During November/December 1984, only flexion larvae were collected in front of Bahía La Paz and south of Guaymas (Fig. 3e).

In June 1986 preflexion larvae were distributed in three main patches: in the southern region of Isla Tiburón; in front of Agiabampo; and in the central region of the mouth of the Gulf (Fig. 3d). Few flexion larvae were found in the region of big islands and postflexion larvae were located in the southeast area of the Gulf (Fig. 3e and f). In August 1986 a continuous distribution of preflexion larvae was observed between Bahía Concepción and Agiabampo, with the highest abundance of larvae located in the deepest area of this region (Fig. 3g). Flexion larvae were distributed in two main patches of high abundance: in front of Guaymas and Bahía Concepción, and between Agiabampo and Bahía La Paz (Fig. 3h). The areas with highest abundance of postflexion larvae were located along the coast south of Bahía Concepción and in front of Agiabampo (Fig. 3i). Distribution of preflexion and flexion larvae during September 1987 was similar to that observed during July 1984. Three patches of high larval density were found: south of Isla 

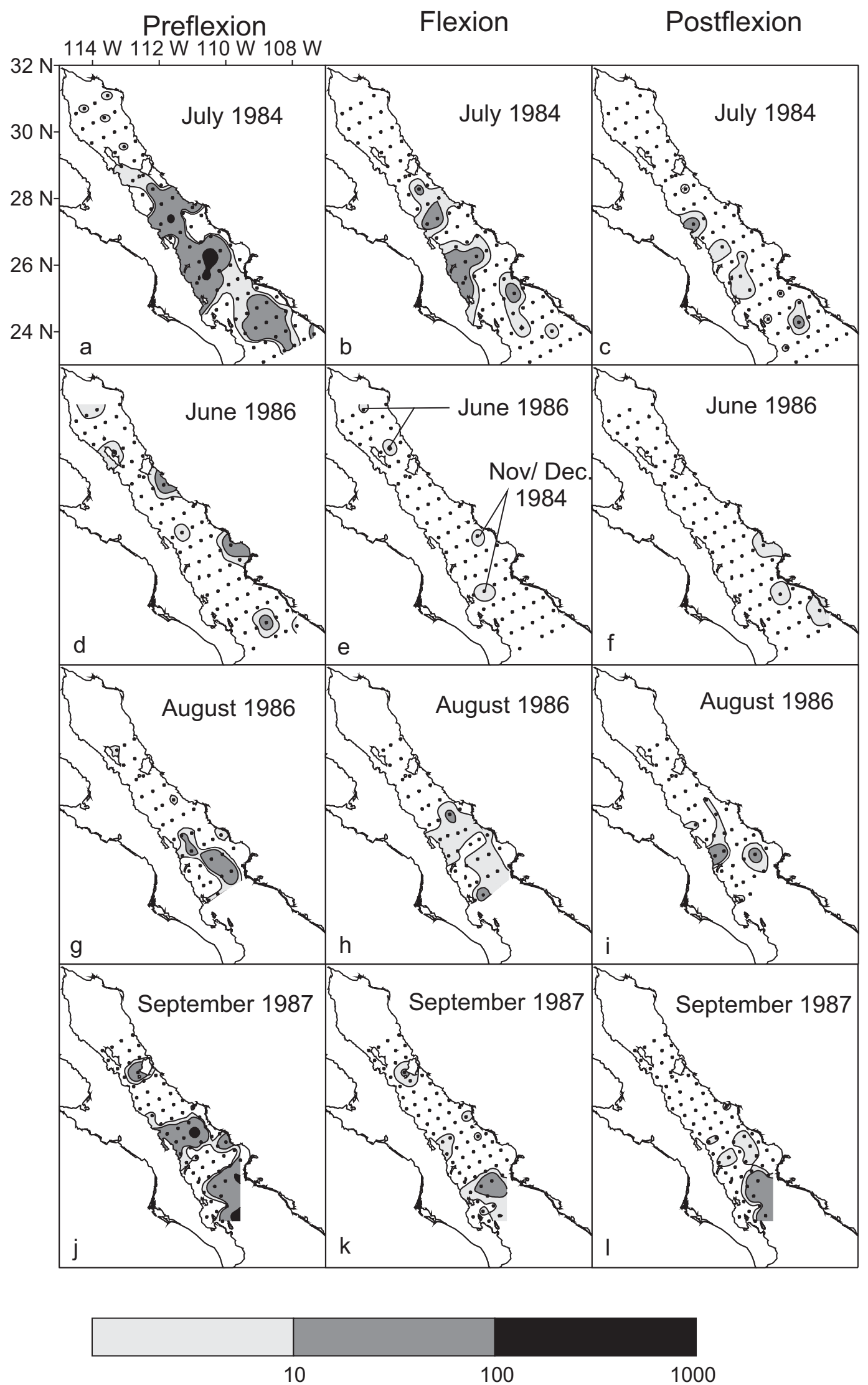

FIG. 3. - Distribution of S. williamsi larvae according to developmental stage. Abundance scale is in organisms per $10 \mathrm{~m}^{2}$ of sea surface. 


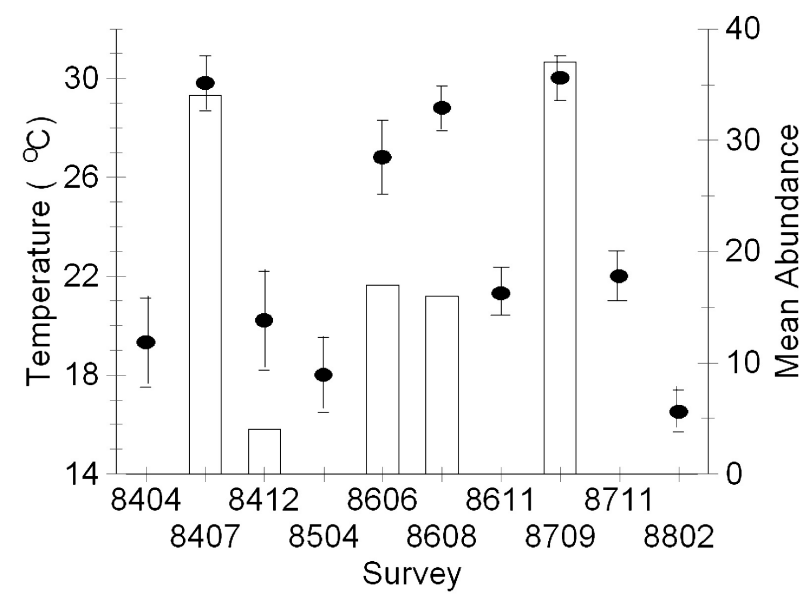

FIG. 4. - Mean sea surface temperature (black circles) with standard deviation (lines), and mean abundance (organisms per $10 \mathrm{~m}^{2}$ ) per survey (bars). The first two digits of the survey label indicate the year, and the last two digits indicate the month.

Tiburón, in front of Bahía Concepción, and south of Agiabampo, but postflexion larvae were abundant mainly between Bahía La Paz and Topolobampo (Fig. 3j-1).
Higher abundances of $S$. williamsi larvae were observed when the Gulf's SST average was above $26^{\circ} \mathrm{C}$ (Fig. 4). Mean SST increased from $19^{\circ} \mathrm{C}$ in April 1984 (with no S. williamsi larvae) to almost $30^{\circ} \mathrm{C}$ in July 1984 (with $99 \%$ of the larvae of that year). Abundance decreased again during November /December to the lowest values of the year at the same time that the mean SST decreased to $20^{\circ} \mathrm{C}$. The same relationship between abundance and SST was observed from summer to autumn 1986, as well as from summer 1987 to winter 1988 (Fig. 4).

Spatially during July 1984, three areas of warm water were found at the surface and at $50 \mathrm{~m}$ depth (Fig. 5a and 6a): between Bahía Concepción and Guaymas; between Isla del Carmen and Agiabampo; and the eastern region of the Gulf's mouth, where the temperature was between 29 and $31^{\circ} \mathrm{C}$ at the surface and 22.5 and $27^{\circ} \mathrm{C}$ at $50 \mathrm{~m}$. The highest abundances of preflexion and flexion larvae were in these warm areas (Fig. 3a and b). Flexion larvae in November and December 1984 (Fig. 3e) were also found in the

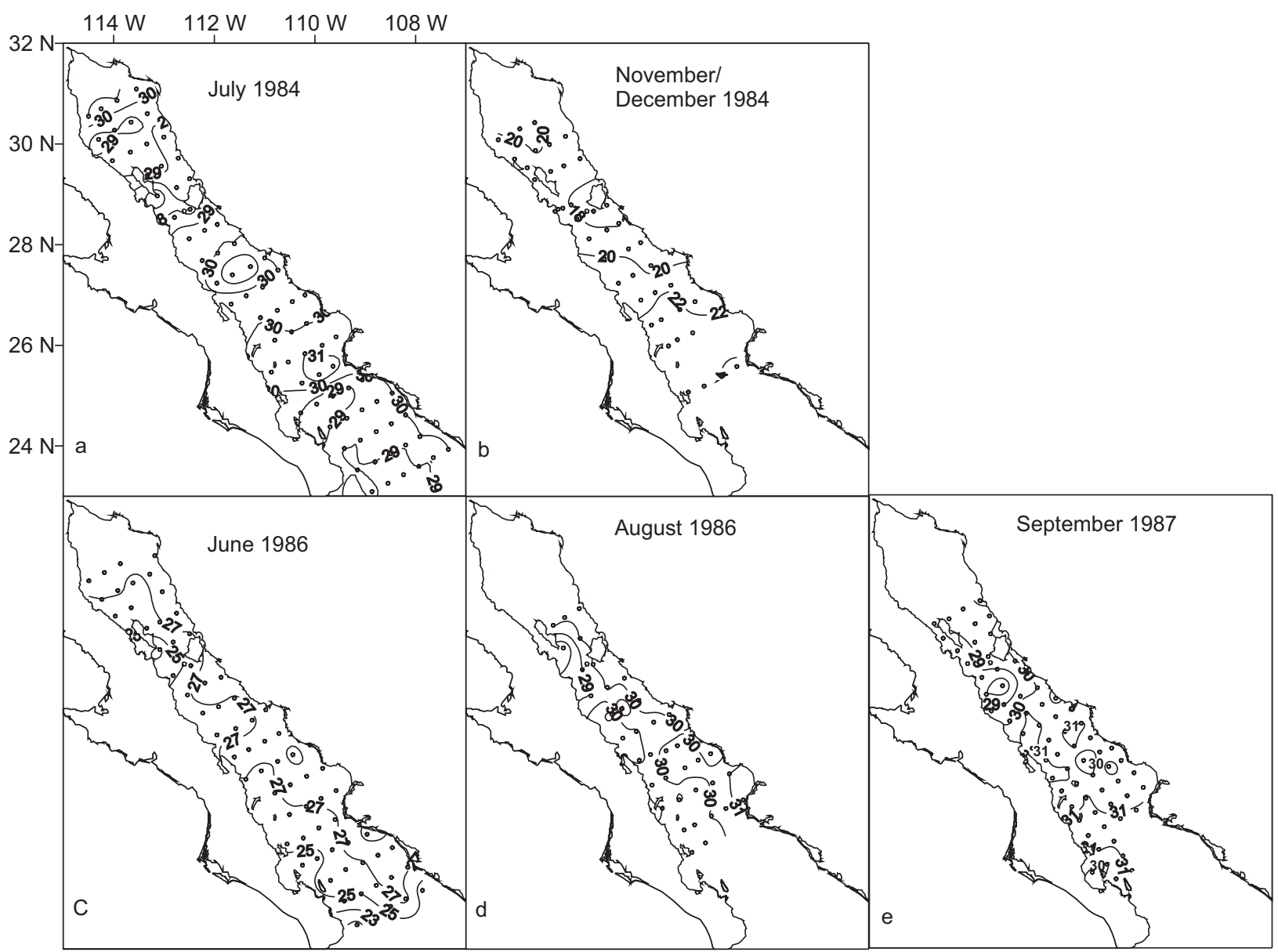

FIG. 5. - Sea surface temperature $\left({ }^{\circ} \mathrm{C}\right)$ during the surveys with $S$. williamsi larvae. 


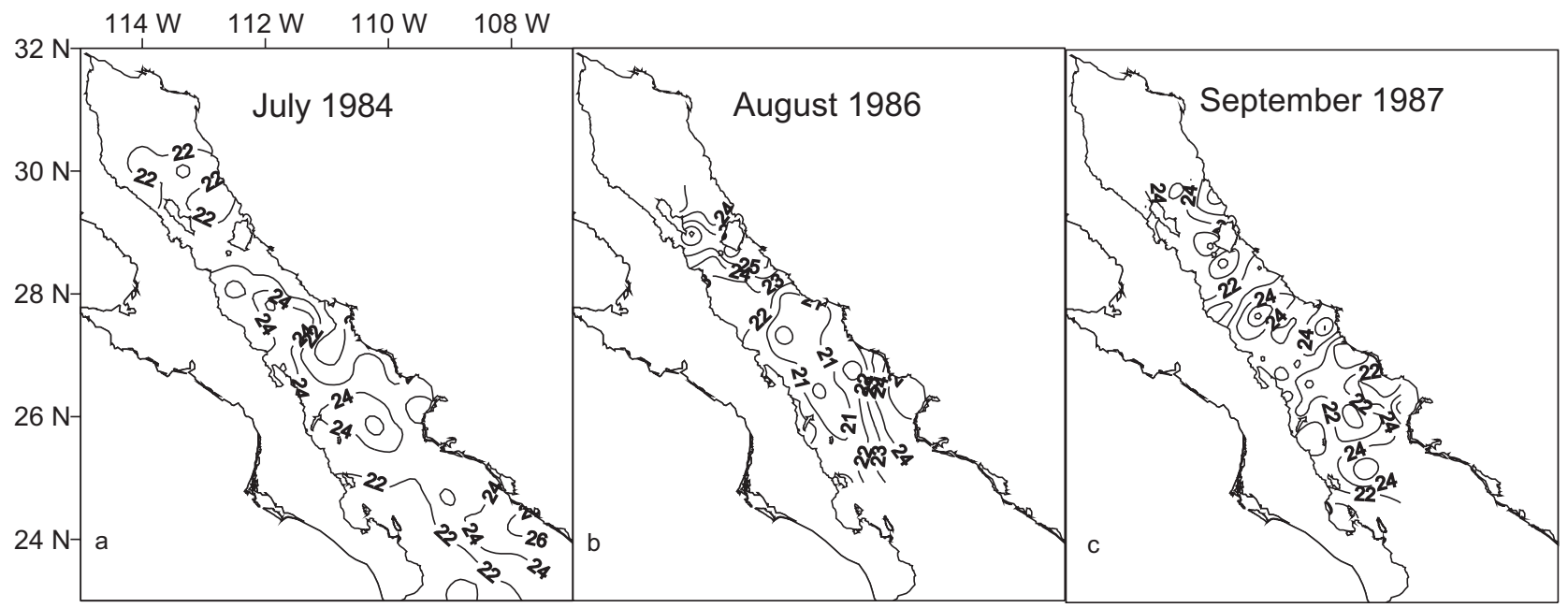

FIG. 6. - Temperature $\left({ }^{\circ} \mathrm{C}\right)$ at $50 \mathrm{~m}$ during the summer surveys.

warmer region south of the Gulf (Fig. 5b). The same spatial relationship with warm regions at the surface and at $50 \mathrm{~m}$ depth can be observed by comparing the
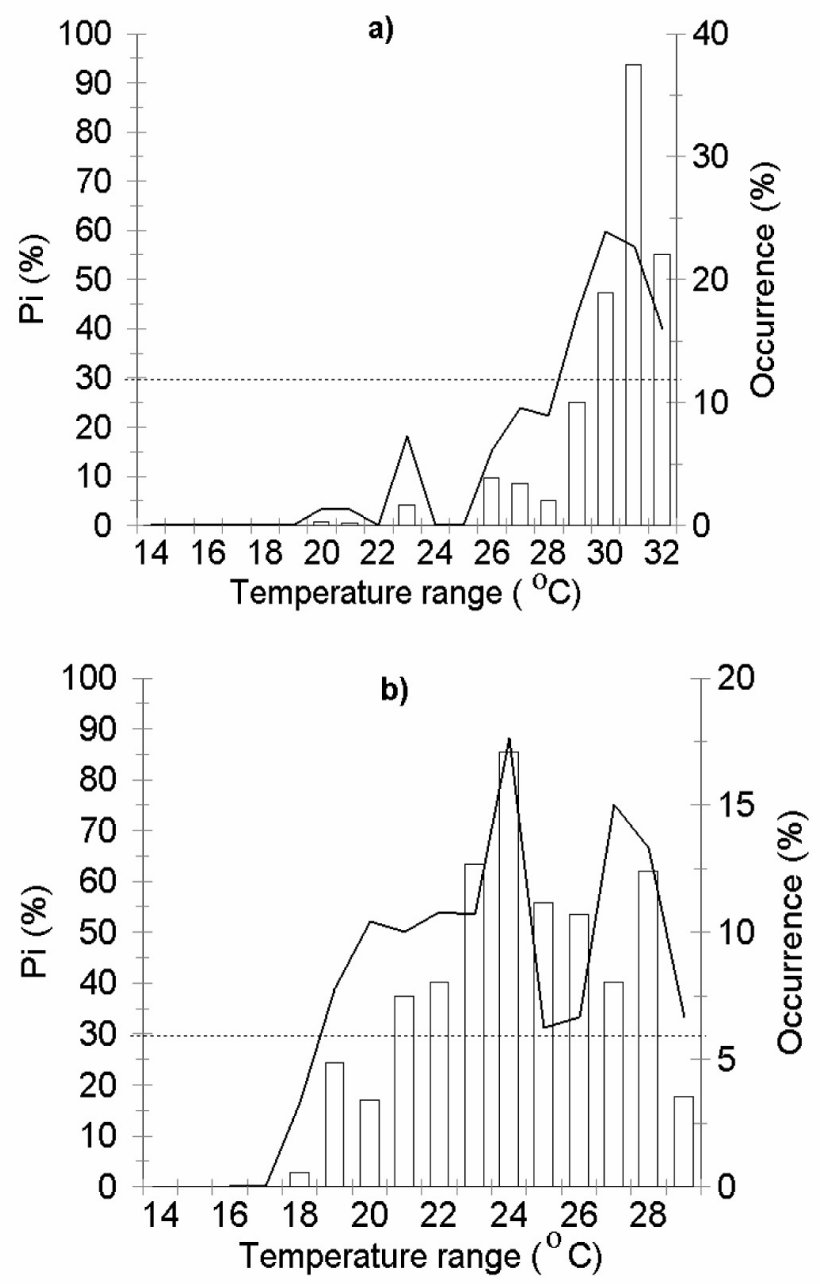

FIG. 7. - Percentage of positive stations (Pi) (lines) and larval occurrence (bars) by temperature range in the 1984 to 1988 period, at: (a) sea surface; and (b) $50 \mathrm{~m}$ depth. temperature maps of June and August 1987 and September 1987 (Figs. 5-6) with that of the preflexion larvae distribution (Fig. 3).

Considering the 535 SST records between spring 1984 and winter 1988, although larvae were found in stations where SST ranged from 18 to $32^{\circ} \mathrm{C}$, almost $90 \%$ of preflexion larvae were in areas where SST was from 29 to $32^{\circ} \mathrm{C}$ (Fig. 7a). The proportion of positive stations with preflexion larvae (Pi) was higher than $30 \%$ in this temperature range. In contrast, at depths of $50 \mathrm{~m}$, stations with preflexion larvae were found over a wider temperature range with $90 \%$ found from 21 to $28^{\circ} \mathrm{C}$, and $\mathrm{P} i$ was over $30 \%$ when temperatures were between 19 to $29^{\circ} \mathrm{C}$, with two peaks of abundance at $24^{\circ} \mathrm{C}$ and $28^{\circ} \mathrm{C}$ (Fig. $7 \mathrm{~b}$ ).

Vertical profiles of temperature in transects 1,2 and 3 of the July 1984 survey (Fig. 8a) show a rise in the isotherms south of Isla Tiburón (lines 0 to 5), between Bahía Concepción and Los Tanques (lines 20 to 25), and south of Bahía La Paz to Topolobampo (lines 40 to 65). Intercalated with these areas of colder water, wide columns of warm water, at least 40 to $50 \mathrm{~m}$ deep, coincide with greater larval density. Along the west (1) and central (2) transects, two peaks of maximum abundance of preflexion larvae were found over the Guaymas basin (line 15), and the Carmen basin (line 30) (Fig. 1) coinciding with the $30^{\circ} \mathrm{C}$ isotherm (Fig. 8a). In the east transect (3) two peaks of maximum abundance were also found in a deeper thermocline (Fig. 8a); the first in front of Carmen basin (line 30), and the second in Pescadero basin (lines 50 and 55).

During September 1987 (Fig. 8b), a column of warm water was present as in July 1984 between 
a
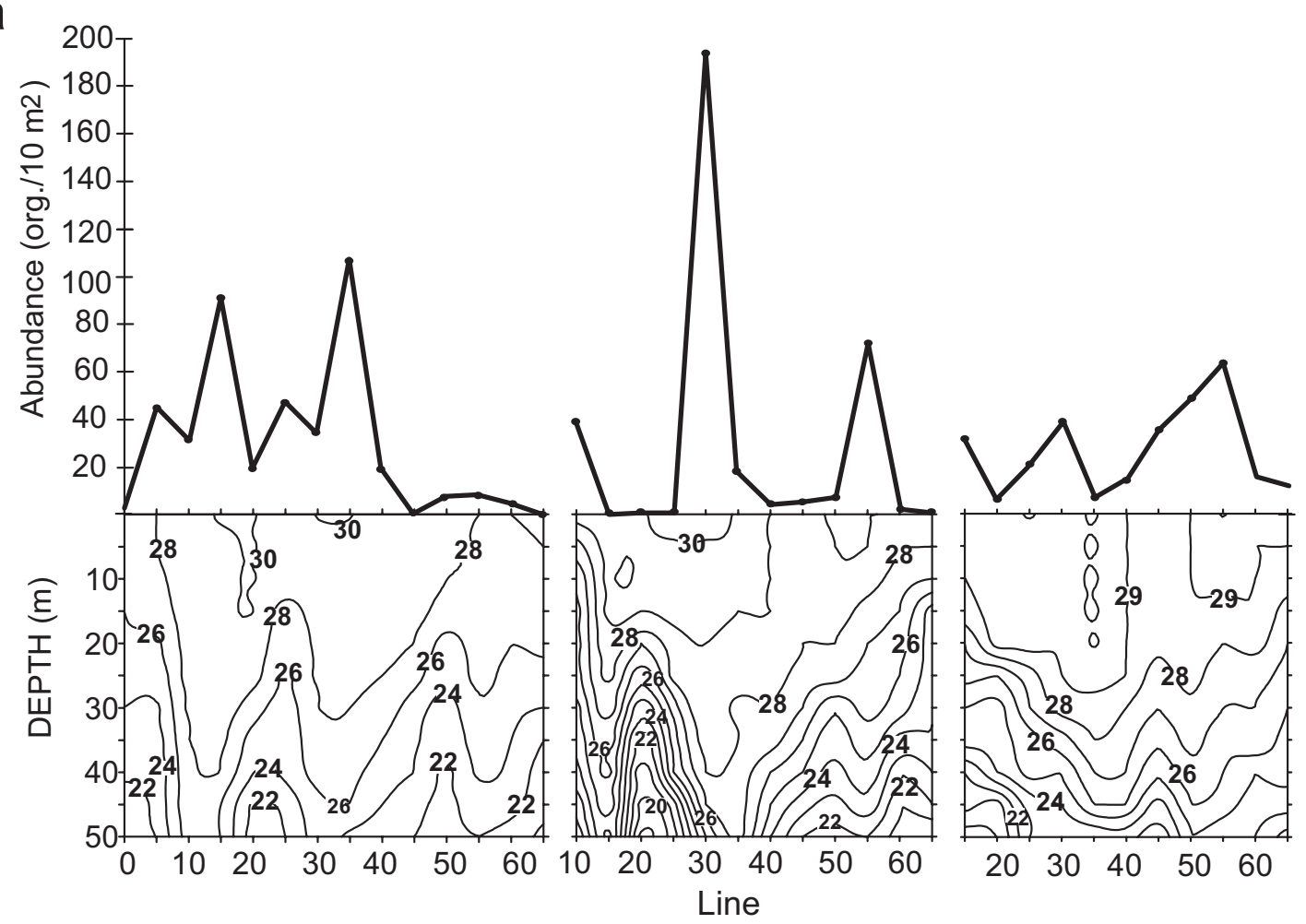

WEST TRANSECT (1)

CENTRAL TRANSECT (2)

EAST TRANSECT (3)

b
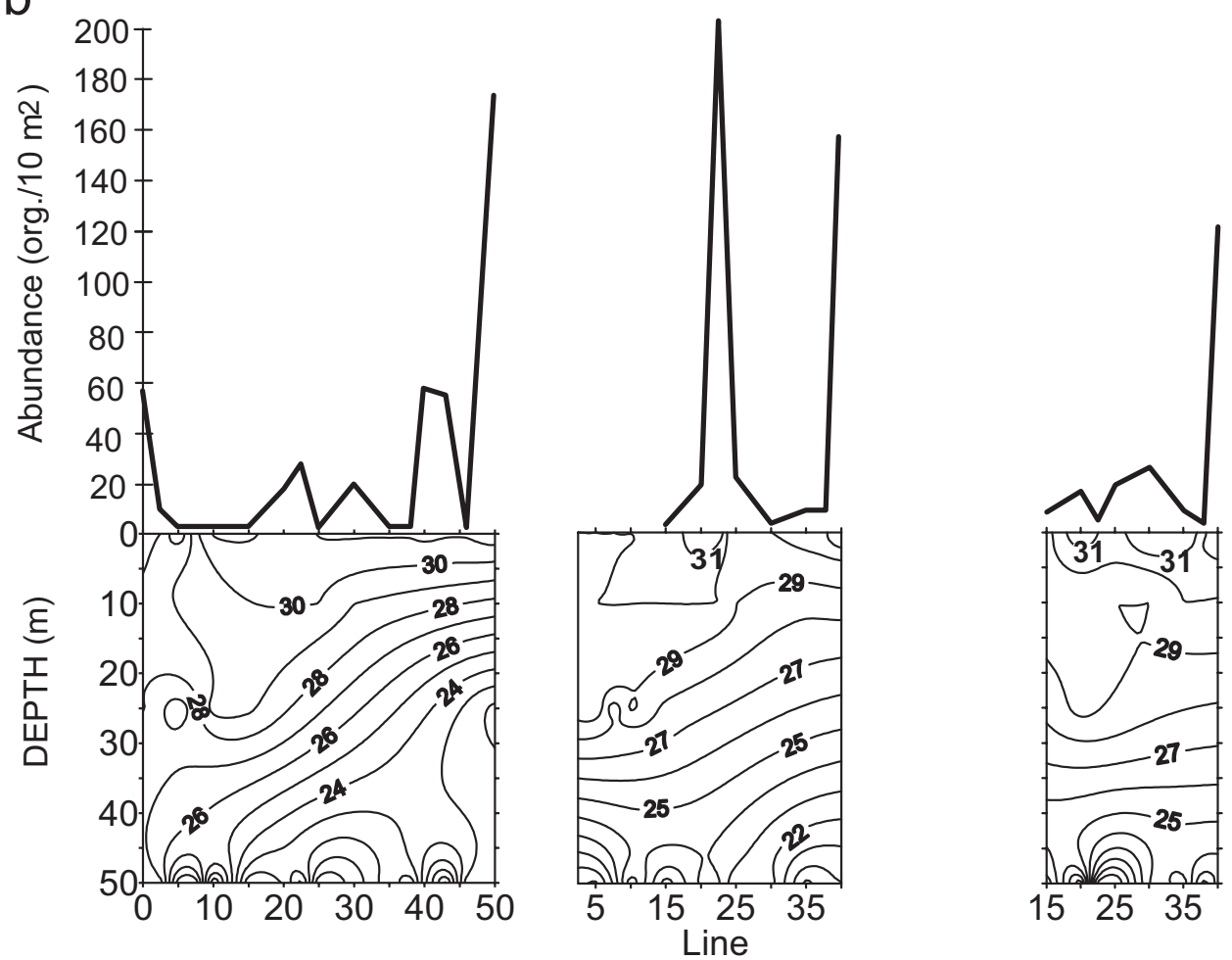

WEST TRANSECT (1)

CENTRAL TRANSECT (2)

EAST TRANSECT (3)

(3)

FIG. 8. - Abundance of preflexion larvae (solid lines), and vertical profiles of temperature over west (1), central (2) and east (3) transects shown in Figure 2 during: a) July 1984; b) September 1987. 
lines 5 and 20 in the west (1) and central (2) transects and there was a rise in the isotherms southward. The length of the transect was shorter during this survey, but peaks of high abundance were also found in areas of 30 to $31^{\circ} \mathrm{C}$.

\section{DISCUSSION}

Although adult Symphurus species are benthic organisms (Munroe et al., 1995), the eggs and larvae are pelagic, like almost all pleuronectiforms. Since early stages of these flatfishes are frequently collected in ichthyoplankton surveys (Ahlstrom et al., 1984; Charter and Moser, 1996), their seasonal occurrences allow us to make indirect assumptions concerning spawning periods and locations.

Using the preflexion stage to identify spawning areas and time of reproduction of particular species may be biased if the developmental period of eggs and preflexion stages are long. However, available data on Symphurus genus larvae suggest a short egg development phase. For example, according to Moser (1984), small hatching size means a short egg period. S. williamsi probably has a hatching size less than 2.2 mm body length (Aceves-Medina et al., 1999), similar to that recorded for S. atricauda, which is unusually less than $1.9 \mathrm{~mm}$ (Charter and Moser, 1996). The shortest body length at eclosion known in pleuronectiformes is $1.3 \mathrm{~mm}$ in Achirus mazatlanus, which has a short egg stage of 4 days (Ortíz-Galindo et al., 1990). A similar hatching size to that recorded for the Symphurus genus is found in Paralichthys californicus and Paralichthys dentatus, which ranges between 1.8 and $2.3 \mathrm{~mm}$, and they have an egg stage of 4 to 5 days (Conklin et al., 2004; Watanabe and Feeley, 2004). In addition, the body length of preflexion larvae in this study ranged from 2.2 to $4.8 \mathrm{~mm}$ (AcevesMedina et al., 1999). Age estimations for the same range of sizes for Symphurus civitatus in the south of the Gulf of Mexico suggest an age of between 13 to 24 days (Flores-Coto, et al., 1992). The above information suggests that $S$. williamsi probably has a short egg period.

Abundance data of preflexion larvae show that the spawning season of $S$. williamsi in the Gulf of California probably starts in early summer, with maximum spawns occurring from July to September. Eight flexion larvae were found in the November-December 1984 survey at two stations facing Bahía de La Paz, perhaps as isolated spawns occurring during late October or early November marking the end of the reproductive period.

Oblique bongo tows were integrative of the entire water column (0-200 m), so it is not possible to determine the depth or the temperature where the larvae were found. Studies made by JiménezRosenberg et al. (unpublished data) in Bahía de La Paz, found larvae mainly between 0 and $50 \mathrm{~m}$ depth, with a low occurrence between 50 and $100 \mathrm{~m}$. Limitations in the knowledge about larval vertical distribution makes the optimum temperature range where they are found unclear. However, temperature appears to play an important role in their distribution and abundance because although a wide temperature range was found throughout the study period, larvae were only captured in a narrow range: $90 \%$ of preflexion specimens occurred between 29 to $32^{\circ} \mathrm{C} \mathrm{SST}$ and the maximum value of $\mathrm{P} i$ (50 to 60\%) was found between 30 to $31^{\circ} \mathrm{C}$. Moreover, the tropical affinity of this species, suggests a strong dependence of the spawn on the tropical warm water that, according to Rosas-Cota (1977), comes to the south of the Gulf during the summer months, which is the period when $S$. williamsi larvae were found.

The reproduction period of $S$. williamsi in the Gulf of California is short in contrast with the warmer eastern Pacific waters off the coast of the Jalisco and Colima area, where larvae are found practically all year, but in lower abundance (Flores-Vargas, 2000). Like other tropical species (Acal and Corro-Espinosa, 1994), S. williamsi, exhibits latitudinal differences in spawning seasonality as a consequence of environmental differences, in which temperature seems to play the most important role. The Gulf of California has a cold period with a mean SST in winter and spring between 16 and $18{ }^{\circ} \mathrm{C}$, while the Jalisco and Colima area has a winter SST closer to $22^{\circ} \mathrm{C}$ (FloresVargas, 2000). These are similar to temperatures observed during the November-December 1984 survey in the southernmost area of the Gulf, where $S$. williamsi larvae were found. A more stable and warm environment supports continuous reproduction to the south, but spawning in the Gulf of California is limited by the more extreme changes in SST between the summer and winter seasons.

Distribution maps based on surveys show that the major reproductive activity occurs in the central and southern regions of the Gulf, which is the area with less environmental changes on a seasonal basis compared with the region north of the big islands that is considered to be a physical barrier for the dis- 
tribution of tropical species (Brinton et al., 1986). Based on increases in abundance of flexion and postflexion larvae from north to south, spawning activity occurs progressively in the direction that warm water from the tropical Pacific enters the Gulf (Rosas-Cota, 1977). This pattern seems to be common in other tropical Pleuronectiformes in the Gulf, such as Bothus leopardinus and Syacium ovale, whose preflexion larvae increase in abundance from south to north during the summer months (AcevesMedina et al., 2003b).

Two important characteristics found in the distribution pattern of $S$. williamsi larvae are: 1) the tendency to appear in patches separated by areas of low concentration or absence of larvae, and 2) preflexion larvae appear in high densities along the longitudinal axis of the Gulf over deeper areas than those where adults are recorded. Since adults occur from 0 to $50 \mathrm{~m}$ but mainly at depths less than $30 \mathrm{~m}$ (Munroe et al., 1995), the presence of high densities of preflexion larvae over the Guaymas Basin (between Bahía Concepción and Guaymas, nearly $1900 \mathrm{~m}$ deep) or over the Carmen Basin (in front of Isla del Carmen, nearly $2500 \mathrm{~m}$ deep), can be explained by offshore transport during the egg stage, which is mainly epipelagic (Ahlstrom et al., 1984; Charter and Moser, 1996). Offshore transport of eggs and early larvae has been described for other Pleuronectiformes, such as Pleuronectes flesus in the English Channel (Grioche et al., 1997) or Syacium ovale in the Gulf of California (AcevesMedina et al., 2003b). Although behaviour plays an important role in the horizontal and vertical movements of fish larvae (Grioche et al., 2000), larval distribution patterns of many Pleuronectiformes can be explained by passive larval drift (Frank et al., 1992).

Two main transport mechanisms for fish larvae have been described for the Gulf of California. Hamman et al. (1988) suggested that winter and spring upwellings generated by winds are responsible for the transport of Sardinops sagax larvae from the continental coast to the peninsular coast. However, Aceves-Medina et al. (2003b) suggested that oceanic gyres during summer could be responsible for the transport of Syacium ovale larvae to the central axis of the Gulf. Semi-permanent cyclonic and anticyclonic gyres have been described as an important feature in the circulation of the Gulf (Emilsson and Alatorre, 1997) that split the area south of the big islands into three regions (Gilbert and Allen, 1943; Round, 1967; Brinton et al., 1986) which coincide with the areas of concentrations of $S$. williamsi larvae.

Similarities in larval distribution of Symphurus williamsi, with those of Syacium ovale, Albula sp. and other larvae of shallow demersal species at the same time and areas of the Gulf (Aceves-Medina, 2003; Aceves-Medina et al., 2003b, 2004), suggest a common reproductive strategy that implies segregation of ontogenetic stages, starting with adults of $S$. williamsi spawning in shallow waters during summer. Preflexion larvae drift offshore towards the central axis of the Gulf of California, where they are found in higher densities. Finally, older larvae return to settlement areas in coastal waters or die in the middle of the Gulf.

The principal reproductive strategies reported in pleuronectiforms are: 1) species that spawn in or near suitable nursery habitats where retention of eggs and larvae is favourable for recruitment, and 2) species that spawn far from their nursery habitats (Van der Veer et al., 1998; Van der Veer and White, 1999; Bailey and Piquelle, 2002). Most flatfish are the latter type (Minami and Tanaka, 1992), as seen in the Gulf of California for S. ovale (Aceves-Medina et al., 2003b) and S. williamsi. This behaviour, common in larvae of other species, has been related to a strategy for finding or remaining in appropriate habitats (Dickey-Collas et al., 1996; Helfman et al., 1997). In some Pleuronectiformes (Pleuronectes flesus and Solea solea), offshore or inshore displacements are coupled with vertical migrations of fish larvae, that help them drift in currents towards different directions (Grioche et al., 2000).

The distribution pattern during 1984 and 1987 suggests that offshore transport of early larvae in the Gulf is frequent. If this is true, then successful recruitment depends on late larval stages being transported to the settlement areas. This is an important conclusion because studies of other demersal species show the same pattern (Aceves-Medina, 2003b). However, more data are needed to prove this hypothesis, especially information related to physical variables of the gyres and vertical distribution of fish larvae.

The positive relationship between preflexion larval abundance and SST temperature, and the spawning period being restricted to the summer season in contrast with year-round spawning in warmer areas, suggest that temperature plays an important role in 
the reproduction of this species in the Gulf of California.

\section{ACKNOWLEDGEMENTS}

CICIMAR-IPN and Coordinación General de Posgrado e Investigación provided financial support through the projects DEPI-86804, DEPI-868043, and DEPI-903388. The authors thank CONACyT, IPN-PIFI, EDI and COFAA for grants. Many thanks to Sylvia P. Jiménez-Rosenberg of IPN CICIMAR for the information on the vertical distribution of $S$. williamsi larvae in the Gulf of California.

\section{REFERENCES}

Acal, D.E. and D. Corro-Espinosa. - 1994. Reproducción y distribución de peces clupeidos en el sur del Golfo de California y Golfo de Tehuantepec, México. Rev. Biol. Trop., 42(1/2): 239-261.

Aceves-Medina, G. - 2003. Grupos de larvas de peces recurrentes en el Golfo de California y costa Occidental de Baja California Sur. Doctoral thesis, CICIMAR-IPN. La Paz, B.C.S., México.

Aceves-Medina, G., E.A. González and R.J. Saldierna. - 1999. Larval development of Symphurus williamsi (Cynoglossidae: Pleuronectiformes) from the Gulf of California. Fish. Bull., 97: 738-745.

Aceves-Medina, G., S.P.A. Jiménez-Rosenberg, A.HinojosaMedina, R. Funes-Rodríguez, R.J. Saldierna, D. Lluch-Belda, P.E. Smith and W. Watson. - 2003a. Fish larvae from the Gulf of California. Sci. Mar., 67: 1-11.

Aceves-Medina, G., R.J. Saldierna-Martínez and E.A. González. 2003b. Distribution and abundance of Syacium ovale larvae (Pleuronectiformes: Paralichthyidae) in the Gulf of California. Rev. Biol. Trop., 51(2): 561-570.

Aceves-Medina, G., S.P. Jiménez, A. Hinojosa, R. Funes, R. Saldierna and P.E. Smith. - 2004. Fish larvae assemblages in the Gulf of California. J. Fish Biol., 65: 1-16.

Ahlstrom, E.H. - 1972. Kinds and abundance of fish larvae in the eastern tropical Pacific on the second multivessel EASTROPAC survey, and observations on the annual cycle of larval abundance. Fish. Bull., 70(4): 1153-1242.

Ahlstrom, E.H., D.A. Hensley, H.G. Moser and B.Y. Sumida. 1984. Pleuronectiformes: Development. In: H.G. Moser, W.J. Richards, D.M. Cohen, M.P. Fahay, A.W. Kendal and S.L. Richardson (eds.), Ontogeny and Systematics of Fishes, pp. 640-670. Spec. Pub. No. 1. Allen Press. Lawrence, Kansas.

Alvarez-Borrego, S. - 1983. Gulf of California. In: Ketchum, B.H. (ed.), Estuaries and Enclosed Seas, pp. 427-449. Elsevier Scientific Publishing Co., Amsterdan.

Bailey, K.M. and S.J. Picquelle. - 2002. Larval distribution of offshore spawning flatfish in the Gulf of Alaska: potential transport pathways and enhanced onshore transport during ENSO events. Mar. Ecol. Progr. Ser., 236: 205-217.

Brinton, E., A. Fleminger and D. Siegel-Causey. - 1986. The temperate and tropical planktonic biotas of the Gulf of California. CalCOFI Rep., 27: 228- 266.

Castro-Aguirre, J.L., H.S. Espinoza-Pérez and J.J. Schmitter-Soto. - 1999. Ictiofauna estuarino lagunar y vicaria de México. LIMUSA. México, D.F.

Charter, S.R. and H.G. Moser. - 1996. Cynoglossidae: Tonguefishes. In: H.G. Moser (ed.), The Early Stages of Fishes in the California Current Region, pp. 1408-1413. CalCOFI Atlas No. 33. Allen Press, Lawrence, Kansas.

Conklin, D.E., R.H. Piedrahita, G.E. Merino, J.B. Muguet, D.E. Bush, E. Gisbert, J. Rounds and M. Cervantes-Trujano. - 2004. Development of California halibut Paralichthys californicus culture. J. Applied Aquacult., 14:143-154.

Dickey-Collas, M., R.J. Gowen and C.J. Fox. - 1996. Distribution of larval and juvenile fish in the western Irish Sea: relationships to phytoplankton, zooplankton biomass and recurrent physical features. Mar. Freshwater Res., 47: 169-181.

Emilsson, I. and M.A. Alatorre. - 1997. Evidencias de un remolino ciclónico de mesoescala en la parte sur del Golfo de California. In: M.F. Lavín (ed.), Contribuciones a la oceanografía física en México, pp. 173-180. Unión Geofísica Mexicana, Monograph No. 3. México, D.F.

Evseenko, S.A. - 1990. Unusual larvae of the marine tonguefish, Symphurus sp. (Cynoglossidae), from central waters of the Eastern Pacific. J. Ichthyol., 30: 148-154.

Evseenko, S.A. and M.I. Shtaut. - 2000. Early stages of development of two species of tongue soles - Symphurus chabanaudi and $S$. prolatinaris (Cynoglossidae:Pleuronectiformes) from central Eastern Pacific. J. Ichthyol., 40: 751-761.

Flores-Coto, C., A. Sánchez-Iturbe, F. Zavala-García and D. LópezGarcía. - 1992. Edad y crecimiento de larvas de Achirus lineatus, Etropus crossotus, Syacium gunteri y Symphurus civitatus en el sur del Golfo de México. An. Inst. Cienc. del Mar y Limnol. Univ. Nal. Autón. México, 19: 167-173.

Flores-Vargas, R. - 2000. Variación espacio temporal de la distribución y abundancia de larvas de pleuronectiformes en las costas de Jalisco y Colima, México. Masters thesis. Universidad de Colima, México.

Frank, K.T., J.W. Loder, J.E. Carscaden, W.C. Leggett and C.T. Tagart. - 1992. Larval flat fish distributions and drift on the southern Grand Bank. Can. J. Fish. Acuacult. Sci., 49: 467-483.

Gilbert, J.Y. and W.E. Allen. - 1943. The phytoplankton of the Gulf of California obtained by the E.W. Scripps in 1939 and 1940. J. Mar. Res., 5(2): 89-110.

Grioche, A., P. Koubbi and B. Sautour. - 1997. Ontogenic migration of Pleuronectes flesus larvae in the eastern English Channel. J. Fish Biol., 51A: 385-396.

Grioche, A., X. Harlay, P. Koubbi and L. Fraga. - 2000. Vertical migrations of fish larvae: Eulerian and Lagrangian observations in the eastern English Channel. J. Plankon Res., 22(10): 1813-1828.

Hamman, M.G., T.R. Baumgarthner and A. Badan-Dangón. - 1988. Coupling of the Pacific sardine (Sardinops sagax caeruleus) life cycle with the Gulf of California pelagic environment. CalCOFI Rep., 29: 102-108.

Helfman, G.S., B.B. Collette and D.E. Facey. - 1997. The Diversity of Fishes. Blackwell Science, Inc. Massachusetts.

Minami, T. and M. Tanaka. - 1992. Life history cycles in flatfish from the northwestern Pacific, with particular reference to their early life histories. Neth. J. Sea Res., 29: 35-48.

Moser, H.G. - 1984. Morphological and functional aspects of marine fish larvae. In: R. Lasker (ed.), Marine Fish Larvae. Morphology, Ecology, and Relation to Fisheries, pp. 89-127. Washington Sea Grant College, University of Washington, Seattle.

Munroe, T.A. - 1992. Interdigitation pattern of dorsal fin pterygiophores and neural spines, an important diagnostic character for Symphurinae tonguefishes (Symphurus: Cynoglossidae: Pleuronectiformes). Bull. Mar. Sci., 50(3): 357-403.

Munroe, T.A., F. Krupp and M. Schneider. - 1995. Cynoglossidae. In: W. Fischer, F. Krupp, W. Schneider, C. Sommer, K.E. Carpenter and V.H. Niem. (eds.), Guía FAO para la identificación de especies para los fines de la pesca, pp. 1039-1059. Vol. III. ONU, FAO. Roma.

Ortíz-Galindo, J.L., E. Matus-Nivón, R. Ramírez-Sevilla and B. González-Acosta. - 1990. Embrión, larva y prejuvenil del sol mexicano Achirus mazatlanus (Pices: Soleidae). Rev. Biol. Trop., 38(2A): 195-204.

Rosas-Cota, A. - 1977. Corrientes geostróficas en el Golfo de California en la superficie y a $200 \mathrm{~m}$, durante las estaciones de invierno y verano. CalCOFI Rep., 19: 89-106.

Round, F.E. - 1967. The phytoplankton of the Gulf of California. Part I. Its composition, distribution and contribution to the sediments. J. Exp. Mar. Biol. Ecol., 1(1): 76-97.

Smith, P.E. and S.L. Richardson. - 1979. Técnicas modelo para prospecciones de huevos y larvas de peces pelágicos. F.A.O. Doc. Tec. Pesca 175. Paris.

Soto-Mardones, L., S.G. Marinone and A. Parés-Sierra. - 1999. Variabilidad espacio temporal de la temperatura superficial del mar en el Golfo de California. Cienc. Mar., 25(1): 1-30. 
Van der Heiden, A.M. - 1985. Taxonomía biología y evaluación de la ictiofauna demersal del Golfo de California. In: A.A. Yañez-Arancibia (ed.), Recursos pesqueros potenciales de México: La pesca acompañante del camarón, pp. 149-200. Prog. Univ. de Alim. Inst. Cienc. Mar y Limnol., Instituto Nacional. de la Pesca. Universidad Nacional Autónoma de México. México, D.F.

Van der Veer, H.W. and J.J. White. - 1999. Year class strength of plaice Pleuronectes platessa in the southern Bight of the North Sea; A validation and analysis of the inverse relationship with winter sea water temperature. Mar. Ecol. Prog. Ser., 184: $245-257$.
Van der Veer, H.W., P. Ruardij, A.J. Van der Berg and $\mathrm{H}$ Ridderinkho. - 1998. Impact of interannual variability in hydrodynamic circulation on egg and larval transport of plaice Pleuronectes platessa L. in the southern North Sea. J. Sea Res. 39: $29-40$.

Watanabe, W.O. and M.W.Feeley. - 2004. Light intensity effects on embryos, prolarvae and first feeding stage larvae of the summer flounder Paralichthys dentatus. J. Applied Aquacult., 14: 179-200.

Scient. ed.: M.P. Olivar

Received September 6, 2004. Accepted September 14, 2005. 